\title{
Chilling Effect as a European Court of Human Rights' Concept in Media Law Cases
}

\author{
TRINE BAUMBACH *
}

\section{Introduction}

Freedom of expression - and freedom to receive and impart information - are protected in Article 10 (1) in the European Convention of Human Rights (the Convention). Since freedom of expression constitutes one of the essential foundations of a democratic society and one of the basic conditions for its progress, ${ }^{1}$ interference by public authority must only take place in accordance with the strict conditions set forth in Article 10 (2). If the case is a media case and it concerns a matter of great public interest, the European Court of Human Rights (the Court) has emphasised that there is only little scope under Article 10 (2) to restrict freedom of expression. ${ }^{2}$

Over time, the Court has found violations of Article 10 in relatively many media cases. In some of these cases the Court has stated that a specific restriction or sanction does not only amount to a violation of Article 10, it also has an actual or has potential chilling effect for press freedom. ${ }^{3}$ Due to that, the Court's scrutiny is (even more) intrusive.

* Associate Professor, PhD, Centre for Public Regulation and Administration, Faculty of Law, University of Copenhagen.

1 See e.g. Couderc and Hachette Filipacchi Associes v. France, appl. no. 40454/07, 10.11.2015 (Grand Chamber), para. 88.

$2 \quad$ See e.g. Mondragon v. Spain, appl. no. 2034/07, 15.3.2011, para. 50.

3 The Court's case law is still relatively modest. See contrary R. O. Fathaigh, Article 10 and the chilling effect principle, European Human Rights Law Review (2013) p. 304. 
The question is, however, what chilling effect means in these cases. Is it just a substitute for a non-proportional restriction or sanction - maybe an extensive one - or is it used in some advanced meaning? In other words, is the term used as a buzzword for anything other than marking an outermost limit of proportionality, or is it possible, by means of the Court's case law, to establish an unassisted content of the notion? That is what this article will examine. Obviously, the analysis will primarily have its legal basis in the Convention and the Court's case law.

To set the right background and context, the Article will, however, begin with a brief review of the rules on the freedom of expression of the press and provide some notes on the Court's common practice in media cases. Eventually, some concluding remarks will be made.

\section{Freedom of Expression in a Free Press Perspective}

\subsection{Freedom of Expression}

As stated above, freedom of expression constitutes on of the essential foundations of a democratic society and one of the basis conditions for its progress. A part of freedom of expression is the right to information, or as stated in Article 10, 'to receive ... information and ideas'. Freedom of the press is deduced from this right, as it is not just the press' role, but also its task to impart information and ideas on all matters of public interest. ${ }^{4}$ The media create the public space for the dissemination of information and the expression of opinions, ${ }^{5}$ since the public cannot possibly gather all relevant information by themselves. The media have also an important role to play regarding the necessary control of the establishment. Without information from the press, the public will be unable to monitor whether the authorities or powerful private enterprises are acting within the framework of a democratic society, governed by the rule of law. Even though many people are on social media to debate important issues, the press is nevertheless needed to ensure that the public debate is qualified. This goes especially regarding the important verifying of information and putting a significant event in context, which is part of the press' duties. If a public debate involves contradictory opinions, the press must objectively reflect the opinions of those involved and refrain from pure sensationalism. ${ }^{6}$ Such demands cannot be made to the public as such, and can thus not be achieved without the involvement of the professional press in the debate.

$4 \quad$ See e.g. Jersild v. Denmark, appl. no. 15890/89, 23.9.1994 (Grand Chamber), para. 31.

5 See also RES. 2035, Draft Resolution of the Council on protection of the safety of journalists and of media freedom in Europe, Brussels, 29 January 2015. 
The press is, in other words, one of the cornerstones of democracy and must, on behalf of the public, play the role of, sometimes said, the 'fourth power' or as the so-called 'public watchdog.' For the press to fill its part, it is paramount that the press is unaffiliated with any extraneous interests and not subjected to restrictions other than those flowing from a pressing social need. The press' reporting must therefore be impartial and conducted in good faith in accordance with the ethics of journalism. This includes the right - not only to impart information and ideas that are favorably received or regarded as either inoffensive or as a matter of indifference - but also to impart information and ideas that offend, shock or disturb. ${ }^{8}$ The Court has also repeatedly emphasised in media cases that press freedom also covers possible recourse to a degree of exaggeration, or even provocation.' 'Such are the demands of that pluralism, tolerance and broadmindedness without which there is no "democratic society." 10 As seen, there is a significant link between the notion of 'necessity' and that of a 'democratic society."11

Any propaganda for war and advocacy of hatred that constitutes incitement to discrimination, hostility or violence (hate speech) are prohibited by law under Article 20 of the United Nations International Covenant on Civil and Political Rights, and constitutes abuse of rights according to Article 17 of the Convention, since it deflects Article 10 from its real purpose and run counter to the fundamental values of the Convention and of democracy. ${ }^{12}$ However, the national laws implementing those prohibitions must not be used against media and journalists who (only) express legitimate political criticism of the government. ${ }^{13}$ What distinguishes a democratic society from a dictatorship is precisely, in a freedom of expression context, the right to openly discuss sensitive and controversial issues of social importance. ${ }^{14}$

$7 \quad$ See Axel Springer AG v. Germany, appl. no. 39954/08, 7.2.2012 (Grand Chamber), para. 78. See also Jacobs, White and Ovey, The European Convention on Human Rights (Oxford University Press 2017) pp. 496 ff., Harris, O’Boyle and Warbrick, Law of the European Convention on Human Rights (Oxford University Press 2014) pp. 640 ff., Schaumburg-Müller, Article 10 in Den Europaiske Menneskerettighedskonvention med kommentarer. Art. 10-59 samt tilloegsprotokollerne, eds. Peer Lorenzen et al. (Jurist- og Økonomforbundets Forlag 2011) pp. 799 and 805, Kjølbro, Den Europæiske Menneskerettighedskonvention for praktikere (Jurist- og Økonomforbundets Forlag 2017) pp. 984 ff. and Baumbach, Medieret - frihed og ansvar (Karnov Group 2017) pp. 65 ff.

$8 \quad$ See Lillo-Stenberg and Sather v. Norway, appl. no. 13258/09, 16.1.2014, para. 28.

$9 \quad$ See e.g. Delfi AS v. Estonia, appl. no. 64569/09, 16.6.2016 (Grand Chamber), para. 132.

$10 \quad$ See e.g. Oberschlick v. Austria, appl. no. 11662/85, 23.05.1991, para. 57.

11 See also Smith and Grady v. the United Kingdom, appl. no. 33985/96, 27.09.1999, para. 87.

12 See Hizb Ut-Tahrir and Others v. Germany, appl. no. 31098/08, 12.06 .2012 (dec.), para. 72 and Belkacem v. Belgium, appl. no. 34367/14, 20.07.2017 (dec.), para. $31 \mathrm{ff}$.

13 See e.g. Fatullayev v. Azerbaijan, appl. no. 40984/07, 22.04.2010, para. 81. See also RES. 2035, Draft Resolution of the Council on protection of the safety of journalists and of media freedom in Europe, Brussels, 29 January 2015.

14 See Perincek v. Switzerland, appl. no. 27510/08, 15.10.2015 (Grand Chamber), para. 204 ff. 


\subsection{Interference with the Right to Freedom of Expression}

Freedom of expression is, as indicated, a qualified but not an absolute right. It is therefore subjected to conditions and restrictions as set forth in Article 10 (2). The provision is constructed in a special way, since it begins with establishing that freedom of expression carries with it 'duties and responsibilities.'

According to Article 10 (2), freedom of expression can be subject to formalities, conditions, restrictions or penalties as are prescribed by law and are necessary in a democratic society. This goes if the interference is in the interests of national security, territorial integrity or public safety, for the prevention of disorder or crime, for the protection of health or morals, for the protection of the reputation or rights of others, for preventing the disclosure of information received in confidence, or for maintaining the authority and impartiality of the judiciary. The close link between 'necessary' in Article 10 (2) and the notion of a 'democratic society' implies, in the Court's interpretation, the existence of a pressing social need and a claim of proportionality. ${ }^{15}$

The High Contracting Parties have a margin of appreciation in assessing whether such a need exists, but it goes hand in hand with the Court's supervision. In this regard, the Court's supervision embraces both the law and the decisions that apply it, even those made by independent national courts. The Court is thus empowered to give the final ruling on whether an interference can be reconciled with freedom of expression. On the other hand, the Court's task is not to substitute the national court but to review under Article 10 the national decision. This does not mean that the Court's supervision is limited to ascertaining whether the national court has exercised its discretion reasonably, carefully and in good faith. The Court must rather examine the interference in the light of the case as a whole and determine whether it was proportionate to the legitimate aim pursued, including if the national court has applied standards, which are in conformity with the principles embodied in Article 10 and relied on an acceptable assessment of the relevant facts. ${ }^{16}$ Lastly, the Court examines whether the reasons adduced by the national authorities to justify its verdict were relevant and sufficient. Thus, the quality of the domestic judicial review is important - not least in cases involving the press. The last-mentioned appears to be of great importance to the Court, and seems to offer the national court, if done properly, a larger margin of appreciation. ${ }^{17}$ This is, presumably, because the

15 See Jacobs, White and Ovey 2017 pp. 486 ff., Harris, O’Boyle and Warbrick 2014 pp. 649 ff., Schaumburg-Müller 2011 pp. 816 ff., Kjølbro 2017 pp. 973 ff. and Baumbach 2017 pp. 75 ff.

16 See Ruokanen and Others v. Finland, appl. no. 45130/06, 06.04.2010, para 51.

17 See e.g. Mikkelsen and Christensen v. Denmark, appl. no. 22918/08, 24.5.2011 (dec.), case LilloStenberg and Seether v. Norway para. 44 and von Hannover v. Germany (No. 2), appl. no. 40660/08, 7.2.2012 (Grand Chamber), para. 104-107 and $117 \mathrm{ff}$. 
Court in these cases can satisfy itself that the national courts in substance have assessed the present case in accordance with required standards. ${ }^{18}$ With the Court's own words:

That it is only by giving reasoned decisions that the domestic courts fulfil the require-

ments of the proper administration of justice. ${ }^{19}$

In cases where the Court is called upon to examine an interference with a media's or journalist's right to freedom of expression, the Court has a well-settled case law establishing that there is only little scope under Article 10 (2) for restrictions on political expressions or on debates on questions of public interest. ${ }^{20}$

\section{Chilling effect - the Court's Case-Law}

\subsection{Selection of Cases}

Below, the Court's case law in media cases will be analysed. The matter in hand concerns media cases where the term 'chilling effect' has been a significant factor in the Court's premises - either in its general principles or in its application of the general principles and the existing case law in the case in question. The case law is selected by means of the search word 'chilling' ${ }^{21}$ in the Court's HUDOC library.

Many media and journalists - and their legal representatives - are very dedicated in their work and keen on their rights. ${ }^{22}$ Therefore, they are not slow to plead 'chilling effect' in media cases. If the Court, however, either rejects the argument without any substantial explanation or does not comment on it at all, the case will not be included in the analysis

18 See e.g. Satakunnan Markkinapörssi Oy and Satamedia Oy v. Finland, appl. no. 931/13, 27.06.2017 (Grand Chamber), para. 198. See also Jacobs, White and Ovey 2017 pp. 360 ff., Harris, O’Boyle,and Warbrick 2014 pp. 510 ff., Schaumburg-Müller 2011 pp. 829 ff., Kjølbro 2017 pp. 980 ff. and Baumbach 2017 pp. 85 f.

19 See Bugan v. Romania, appl. no. 13824/06, 12.2.2013, para. 27. See also Axel Springer SE and RTL Television GmbH v. Germany, appl. no. 51405/12, 21.9.2017, para. 58.

20 See e.g. case Perincek v. Switzerland para. 197. See also Jacobs, White and Ovey 2017 pp. 486 ff., Harris, O’Boyle and Warbrick 2014 pp. 639 ff., Schaumburg-Müller 2011 p. 824, Kjølbro 2017 p. 985 and Baumbach 2017 pp. $101 \mathrm{ff}$.

21 Not 'chilling effect' to avoid overlooking any relevant case due to wrong inflectional forms. There is not found any relevant cases by the search word (effet de) 'refroidissement.'

22 The same goes for third-party interveners plead, see e.g. Medzlis Islamske Zajednice Brcko and Others v. Bosnia and Herzegovina, appl. no. 17224/11, 27.06.2017 (Grand Chamber), para. 63. 
- notwithstanding if the Court found a violation of Article 10 or not. ${ }^{23}$ The case is thus not considered able to enlighten the subject matter. The same goes if the term solely is mentioned in a dissenting opinion without further elaboration, because (the majority of) the Court knew of this opinion before delivering its judgment and did not accept the argument. ${ }^{24}$

By way of introduction, it is to be ascertained that the Court does not find a criminal conviction (in comparison to civil conviction) in itself excessive or to be of such a kind as to have a chilling effect on the exercise of media freedom. ${ }^{25}$ Therefore, the analysis below will not have that distinction in focus. The same is true regarding the burden of proof in defamation cases, where the legal basis in most domestic countries is founded on a principle of 'presumption of falsity.'26

\subsection{Preliminary Remarks}

Initially, it must be noted that the whole idea of a legal system of enforcement - not least the criminal legal system - is that not just the law as such, but also convictions and sanctions are supposed to have a preventive effect - both as an individual deterrence and as a general deterrence. The purpose of the law is to make the public and legal entities refrain from violating the law in the future, so that the law can have a 'happy moment. ${ }^{27}$ This fact must have as implication that chilling effect must refer to something more advanced than deterrence in its ordinary sense. To this must be added that deterrence points at illegal conduct - it is future illegal conduct of the subjects that the legal system wants to deter. Chilling effect goes further or points in a more sophisticated direction - namely

See e.g. case Delfi AS v. Estonia para. 73, case Couderc and Hachette Filipacchi Associes v. France para. 47, Dorota Kania v. Poland, appl. no. 44436/13, 04.10.2016, para. 51 and case Mikkelsen and Christensen v. Denmark.

24 See e.g. Bedat v. Switzerland, appl. no. 56925/08, 29.03.2016, (Grand Chamber), dissenting opinion of judge Lopez Guerra, para. 15 and dissenting opinion of judge Yudkivska, who only stated that 'any criminal sentence inevitably has a "chilling effect".

25 See Frisk and Jensen v. Denmark, appl. no. 19657/12, 05.12.2017, para. 77.

26 See The Wall Street Journal Europe SPRL and Others v. the United Kingdom, appl. no. 28577/05, 10.02.2009 (dec.).

$27 \quad$ A Danish legal scholar has called that moment (if its exist at all) where the law is not violated as 'the happy moment of the law'. See Blume, Anmeldelse: Rettens lykkelige øjeblik, Juristen (2009) p. 176. 
at conduct not necessary illegal in itself..$^{28}$ Deterrence and chilling effect can thus not be said to be synonyms.

In the analysis below, it is important to take into consideration that the reading of the term 'chilling effect' must not amount to an over-interpretation since one can never be entirely certain that the Court, with all its chambers, populated with judges from all over Europe, educated in different legal cultures, et cetera, always is completely stringent in its use of a specific term in cases, such as the current, where the term has not been made into a 'Convention notion'. How vital this observation is for the analysis is inexact. Presumable, it does not have any bearing to the final result, given that this article's objective is not to put forward an exact definition - only to give an indication of cases or circumstances that give rise to using that strong term. On the other hand, it is necessary to have the reservation in mind.

\subsection{The Court's Case-Law}

\subsubsection{Dividing the case-law into categories}

The case law found by the research method can be categorised in various ways, since many of them are alike (but not just the same) or contain similar elements. Below, I have classified them in six categories, plus a compilation category in view of the type of chilling effect and to avoid having immeasurable many categories. The last of these categories is distinct. It goes beyond all the others because the cases in this category are of a special nature due to the underlying domestic cases. They are not alike, but all of them are remarkable. The category is thus named 'remarkable cases'.

\subsubsection{Deprived of the right to work as a journalist}

Since the task of the press, as mentioned above, is to impart information and ideas on all matters of public interest, deprivation of the right to work as a journalist is of exceptional interest in a chilling effect-context.

The case Kaperzynski v. Poland regards an applicant, a journalist and editor-in-chief, who was criminal convicted for not having published a reply. He was sentenced to four

28 See also Times Newspapers LTD v. the United Kingdom, appl. no. 3002/03, 10.02.2009, para. 48 , where the Court emphasised that libel proceedings brought against a newspaper after a significant lapse of time may well, in the absence of exceptional circumstances, give rise to a disproportionate interference with press freedom under Article 10. At the same time, the Court stated that it was not necessary for the Court to consider if the (lengthy) right to take proceedings had a chilling effect. 
months' restriction of liberty in the form of twenty hours community service per month. This part of the conviction was suspended for a period of two years. Furthermore, he was deprived of the right to exercise the profession of journalism for a period of two years. While the Court agreed with the domestic courts that the applicant had failed in his professional duties, the Court held in particular that the sanction of denying him the right to work as a journalist had a chilling effect. The Court stated:

\begin{abstract}
... the Court must exercise caution when the measures taken or sanctions imposed by the national authorities are such as to dissuade the press from taking part in a discussion of matters of legitimate public concern. The chilling effect that the fear of criminal sanctions has on the exercise of journalistic freedom of expression is evident. This effect, which works to the detriment of society as a whole, is likewise a factor which goes to the proportionality, and thus the justification, of the sanctions imposed on media professionals. The same considerations apply in the circumstances of the present case.
\end{abstract}

The Court is of the view that a criminal sentence depriving a media professional of the right to exercise his or her profession must be seen as very harsh. Moreover, it heightens the above mentioned danger of creating a chilling effect on the exercise of public debate. Such a conviction imposed on a journalist can only be said to have, potentially, an enormous dissuasive effect for an open and unhindered public debate on matters of public interest. $^{29}$

The Court made a point of the detriment of society as a whole - that is of a factor beyond the case in hand.

\title{
3.3.3. Protection of journalistic sources
}

Freedom of the press implicates an extended freedom of expression. Included herein is the right of journalists to protect the identity of their sources. In several cases, the Court has commented and underlined that an order of source disclosure has a potentially chilling effect on the exercise of freedom of expression. This is due to the importance of the protection of journalistic sources for press freedom in a democratic society. In the Court's words:

Protection of journalistic sources is one of the basic conditions for press freedom, as is reflected in the laws and the professional codes of conduct in a number of Contracting States and is affirmed in several international instruments on journalistic freedoms... Without such protection, sources may be deterred from assisting the press in informing 
the public on matters of public interest. As a result, the vital public-watchdog role of the press may be undermined and the ability of the press to provide accurate and reliable information may be adversely affected. Having regard to the importance of the protection of journalistic sources for press freedom in a democratic society and the potentially chilling effect an order of source disclosure has on the exercise of that freedom, such a measure cannot be compatible with Article 10 (art.10) of the Convention unless it is justified by an overriding requirement in the public interest. ${ }^{30}$

The Court stress' in these cases that the bedrock principle behind the source protection is twofold, relating not only to the journalist, but also - and in particular - to the source who volunteers to assist the press in informing the public about matters of public interest. ${ }^{31}$ These lines together with the statement of chilling effect must be interpreted as a reference to the extensive effects of the order - reaching further than the case in hand. The same goes with regard to seizure of journalists' confidential source material. ${ }^{32}$

\subsubsection{The criminal conviction itself}

In Dmitriyevskiy v. Russia, the applicant, an editor, was convicted of hate speech in connection with articles regarding the conflict in the Chechen Republic published in the applicant's newspaper but (presumably) written by others. He was given a suspended prison sentence of two years and four years' probation. The Court questioned the sentence because - in the Court's opinion - the publication could not be categorised as hate speech as such. The Court emphasised that particular caution is called for when consideration is being given to the publication of views of representatives of organisations which resort to violence against the State, lest the media become a vehicle for the dissemination of 'hate speech' and the promotion of violence. At the same time, where such views cannot be categorised as such, Contracting States cannot, with reference to the protection of national security or the prevention of crime or disorder, restrict the right of the public to be informed of them by bringing the weight of the criminal law to bear on the media. Then the Court stated:

30 See Goodwin v. the United Kingdom, appl. no. 17488/90, 27.03.1996, para. 39.

31 See case Goodwin v. the United Kingdom para. 39, Voskuil v. the Netherlands, appl. no. 64752/01, 22.11.2007, para. 65, Financial Times LTD and Others v. the United Kingdom, appl. no. 821/03, 15.12.2009, para. 59 and 70, Telegraaf Media Nederland Landelijke Media B.V. and Others v. the Netherlands, appl. no. 39315/06, 22.11.2012, para. 127, Nagla v. Latvia, appl. no. 73469/10, 16.07.2013, para. 80 and 82, Stichting Ostade Blade v. the Netherlands, appl. no. 8406/06, 27.05.2014 (dec.), para. 64 and Becker v. Norway, appl. no. 21272/12, 05.10.2017, para. 65 and 82.

32 See Sanoma Uitgevers B.V. v. the Netherlands, appl. no. 38224/03, 14.09.2010 (Grand Chamber), para. 65 and 71. 
In the Court's opinion, it is not so much the severity of the applicant's sentence but the very fact that he was criminally convicted that is striking in the present case... The Court considers that both the applicant's conviction and the severe sanction imposed were capable of producing a chilling effect on the exercise of journalistic freedom of expression in Russia and dissuading the press from openly discussing matters of public concern, in particular, those in relation to the conflict in the Chechen Republic. ${ }^{33}$

As we shall see below, a severe sanction imposed can have a chilling effect. However, the most important point in this case is that the Court attaches significant importance to the criminal conviction and states that it was the most noteworthy of the domestic judgment, and that not just the severe sanction imposed but also the conviction itself was capable of producing a chilling effect on the exercise of journalistic freedom.

The same is true if the domestic courts - without due validity - disregard 'the journalistic reporting privilege ${ }^{34}$ and thus convict a journalist for assisting in the dissemination of statements made by another person in an interview - since this 'must undeniably have had a chilling effect on the exercise of his right to freedom of expression and may have discouraged him from publishing further critical materials on matters of public interest. ${ }^{35}$

In continuation hereof, it may have a chilling effect on the freedom of expression on the Internet if a non-commercial website is held liable for third-party comments instead of the accrual authors of the relevant comments. ${ }^{36}$

Although the Court relied on the concrete circumstances of the cases, the Court's premises were of a general nature and were suitable to be transformed into legal principles.

\subsubsection{Lenient sanction imposed}

In some cases, the fact of a person's conviction may be, as we have seen, more important that the minor nature of the penalty imposed. On the other hand, if the conviction was legitimate and had no adverse material consequence for the journalist's work to-be, and

33 See Dmitriyevskiy v. Russia, appl. no. 42168/06, 03.10.2017, para. 117.

34 See Baumbach, Are Journalists to be Punished for Doing their Job?, Bergen Journal of Criminal Law and Criminal Justice (2016) p. 107.

35 See Godlevskiy v. Russia, appl. no. 14888/03, 23.10.2008, para. 36 and 45.

36 See Magyar Tartalomszolgaltatok Egyesülete and Index.hu ZRT v. Hungary, appl. no. 22947/13, 02.02.2016, para. 86 . 
the sanction imposed did not in itself have a chilling effect, the conviction can hardly have any chilling effect - even though the journalist is convicted in the line of duty. ${ }^{37}$

Conversely, a minor or very lenient sanction does not necessarily erase the chilling effect which the conviction has induced. ${ }^{38}$ The Government can therefore have a case to answer, even though the sanction imposed was infinitesimal. ${ }^{39}$ This was for instance the case in Dupuis and Others v. France. The applicants were two French journalists. They were convicted of using information obtained through a breach of the confidentiality of an investigation or of professional confidentiality. The information was published in a book composed by them, regarding the so called 'Elysée eavesdropping' operations in France - an illegal system of telephone tapping and record-keeping organised by the highest office of the French state and directed against several figures from civil society, including numerous public figures, journalists and lawyers. Each of the journalists was ordered to pay a fine and to jointly and separately to pay an injured party damages. The book continued to be published and no copies were seized.

The Court found a violation of Article 10, and emphasised in many words that the subject of the book concerned a debate which was of considerable public interest. The Court ended its premises by stating that if an interference with freedom of expression had a chilling effect on the exercise of that freedom, a relatively moderate nature of a fine would not suffice to negate that effect. ${ }^{40}$

The same was true in Instytut Ekonomichnykh Reform, Tov v. Ukraine. This case concerned defamation proceedings (about the motives for a politician to run for parliament held in satirical terms). The applicant, a newspaper, was, by the domestic courts, ordered to retract the statements in question and to pay the politician an amount of money in compensation. The Court, which found a violation of Article 10, stated in respect to the chilling effect:

While the sanction imposed on the applicant company was relatively modest, it nevertheless had symbolic value and it cannot be ruled out that it could still have a chilling effect on the applicant company and other participants in the public debate. ${ }^{41}$

37 See Arnarson v. Iceland, appl. no. 58781/13, 13.06.2017, para. 46, Haldorsson v. Iceland, appl. no. 44322/13, para. 54 and Marco Travaglio v. Italy, appl. no. 64746/14, 24.01.2017 (dec.), para. 37. See also Pentikäinen v. Finland, appl. no. 11882/10, 20.10.2015, (Grand Chamber) para. 113 and Pedersen and Baadsgaard v. Denmark, appl. no. 49017/99, 17.12.2004, (Grand Chamber) para. 93.

38 See Rusu v. Romania, appl. no. 25721/04, 08.03.2016, para. 22.

39 As the Government pleaded in case Jersild v. Denmark para. 29.

$40 \quad$ See Dupuis and Others v. France, appl. no. 1914/02, 07.06.2007 para. 48.

${ }_{41}$ See Instytut Ekonomichnykh Reform, Tov v. Ukraine, appl. no. 61561/08, 02.06.2016, para. 65 (my italicising). See also GRA Stiftung gegen Rassismus und Antisemitismus v. Switzerland, appl. no. 18597/13, 09.01.2018, para. 78 . 
Finally in this paragraph, the Lombardo and Others $v$. Malta-case shall be pointed out. The case concerns defamation proceedings directed towards the applicants by a local council. The applicants had published an article stating that the local council had not consulted the public and was ignoring public opinion in respect of a local road project. The article formed part of an ongoing political debate at that time. The subject matter was therefore of public interest to the local community. The Court found a violation of Article 10 and stated regarding the chilling effect:

\begin{abstract}
Notwithstanding the relatively low amount of damages awarded, the sanction imposed could be considered to have had a chilling effect on the exercise by the applicants of their right to freedom of expression as it was capable of discouraging them from making statements critical of the Local Council's policies in the future. ${ }^{42}$
\end{abstract}

The respondent state may still have a case to answer, even though the sanction imposed is lenient. If the measures taken or the sanctions imposed have - despite of their lenient nature - a chilling effect due to e.g. the implications of the future debate on the subject, the Court will find a violation of Article 10.

\title{
3.3.6. (Suspended) prison sentences
}

In the Krasulya v. Russia-case, the applicant, an editor-in-chief, was found guilty of defamation in a case regarding an issue of public concern. He was sentenced to one year's suspended prison with six months conditional probation. The Court attached importance to the fact that notwithstanding the fact that the sentence was suspended, the applicant was faced with the threat of imprisonment. The sentence was suspended on the condition that the applicant did not commit any further offence in his capacity as editor. That condition had a chilling effect on the applicant in restricting his journalistic freedom and reducing his ability to impart information and ideas on matters of public interest. ${ }^{43}$

In Mariapori v. Finland, the applicant was found guilty of defamation in the context of a debate on an important matter of legitimate public interest. She was sentenced to a suspended prison sentence. The Court stated that such a sanction, by its very nature, will inevitably have a chilling effect on public debate. The fact that the applicant's prison sentence was conditional, and that she did not in fact serve it did not alter that conclusion. ${ }^{44}$ The essence of the case was the same in Mahmudov and Agazade v. Azerbaijan. Here, the applicants were convicted for insult and defamation, which in the Court's opinion met a pressing social need. The applicants were, however, imposed a prison sentence, which the Court found had a chilling effect on the exercise of journalistic freedom. They

\footnotetext{
42 See Lombardo and Others v. Malta, appl. no. 7333/06, 24.04.2007, para. 61.

$43 \quad$ See Krasulya v. Russia, appl. no. 12365/03, 22.02.2007, para. 44.

$44 \quad$ See Mariapori v. Finland, appl. no. 37751/07, 06.07.2010, para. 68.
} 
did not serve their prison sentences but this was only owing to a fortunate coincidence of an amnesty act, which happened to apply to a wide variety of criminal cases at the relevant period of time and which was not adopted with a specific aim of redressing the applicants' particular situation. Thus, the amnesty did not make the Court modify or alter its conclusion. ${ }^{45}$ The Court emphasised that even a general risk of being sentenced to imprisonment - as one of the standard sanctions imposable for unjustified attacks on the reputation of private individuals - has a chilling effect on the exercise of journalistic freedom of expression. ${ }^{46}$ This conclusion, however, was modified in the Yleisradio Oy and Others $v$. Finland-case. The applicants were a broadcasting company and two press officers. They were convicted of (contribution to) disclosing confidential information from a sealed judicial case file in a broadcast on a national TV channel entitled 'Doctors as judg$e s$ '. The programme involved undoubtedly elements of general importance and interest. However, the general public interest had not justified broadcasting such - identifying information. The fact that the two of the applicants had faced the possibility of a prison sentence being imposed on them did, however, not have a chilling effect. ${ }^{47}$

The Cumpana and Mazare v. Romania-case is a leading case in the area of (suspended) prison sentences to media officers. It was handed down by the Grand Chamber in 2004. The core point of the case regarding the chilling effect was the fact that the Court did not find a violation of Article 10 because of the conviction in itself, but merely because of the severity of the penalties imposed on the applicants. The applicants were convicted of insult and defamation and sentenced to seven months' imprisonment. They were also disqualified from exercising certain civil rights and prohibited from working as journalists for one year. In addition, they were ordered to pay non-pecuniary damage to the plaintiff. An appeal by the applicants was dismissed, and so was the Procurator-General's appeal to the Supreme Court of Justice. The Procurator-General submitted that the offence of insult had not been made out, that the amount of damages awarded to the plaintiff had been too high and that there had been no justification for prohibiting the applicants from practising their profession. Approximately six months later the applicants were granted a presidential pardon dispensing them from having to serve their prison sentence. The Court referred to the 'margin of appreciation' and stated that in the circumstances of the case, the domestic authorities were entitled to consider it necessary to restrict the exercise of the applicants' right to freedom of expression and that the applicants' conviction for insult and defamation accordingly met a 'pressing social need'. Hence, the only remaining

$45 \quad$ See Mahmudov and Agazade v. Azerbaijan, appl. no. 35877/04, 18.12.2008, para. 51.

$46 \quad$ See case Mahmudov and Agazade v. Azerbaijan para. 49.

47 See Yleisradio Oy and Others v. Finland, appl. no. 30881/09, 08.02.2011 (dec.). The applicants were only sanctioned pecuniary. 
issue was to determine whether the interference was proportionate to the legitimate aim pursued in view of the sanctions imposed. ${ }^{48}$

The Court emphasised that although the Contracting States have a positive obligation under Article 8 to regulate the exercise of freedom of expression so as to ensure adequate protection by law of individuals' reputations, they must not do so in a manner that unduly deters the media from fulfilling their role of alerting the public to apparent or suspected misuses of public power. Hereafter the Court stated:

Investigative journalists are liable to be inhibited from reporting on matters of general public interest - such as suspected irregularities in the award of public contracts to commercial entities - if they run the risk, as one of the standard sanctions imposable for unjustified attacks on the reputation of private individuals, of being sentenced to imprisonment or to a prohibition on the exercise of their profession.

The chilling effect that the fear of such sanctions has on the exercise of journalistic freedom of expression is evident... This effect, which works to the detriment of society as a whole, is likewise a factor which goes to the proportionality, and thus the justification, of the sanctions imposed on the present applicants, who, as the Court has held above, were undeniably entitled to bring to the attention of the public the matter of the signing of the partnership agreement between the city authorities and the private company concerned.

\begin{abstract}
Although sentencing is in principle a matter for the national courts, the Court considers that the imposition of a prison sentence for a press offence will be compatible with journalists' freedom of expression as guaranteed by Article 10 of the Convention only in exceptional circumstances, notably where other fundamental rights have been seriously impaired, as, for example, in the case of hate speech or incitement to violence. ${ }^{49}$
\end{abstract}

The Court completed the premises by stating that the fact that the applicants did not serve their prison sentences did not alter the conclusion that such a sanction, by its very nature, will inevitably have a chilling effect. This was because the pardon did not expunge their conviction, and because the individual pardons they received were subject to the discretionary power of the President of Romania. Furthermore, the Court attached importance to the other sanctions imposed on them - especially the order prohibiting the applicants from working as journalists for one year. On this particular subject, the Court reiterated its concern regarding prior restraints on the activities of journalists and stated that although it did not appear from the circumstances of the case that the prohibition had had any significant practical consequences for the applicants, the prohibition was particularly severe and could not in any circumstances have been justified by the mere

48 See Cumpana and Mazare v. Romania, appl.no. 33348/96, 17.12.2004, para. 110.

49 See case Cumpana and Mazare v. Romania para. 113-115. See also case Fatullayey v. Azerbaijan para. $102 \mathrm{ff}$. 
risk of the applicants' reoffending. The prohibition, albeit subject to a time limit, accordingly contravened the principle that the press must be able to perform the role of a public watchdog in a democratic society. ${ }^{50}$

The Court's premise seems to have been composed with care and serves as an excellence example of the sanctions' independent significance, both in general and regarding any chilling effect in media law cases. It is understood that the sentencing to imprisonment or the order prohibiting the applicants from exercising their profession were the core objection and pointed towards their future exercise of their profession.

\subsubsection{The total extent of sanctions}

Even though a journalist is not sentenced to imprisonment, the extent of the sanction, including damages and legal costs, can go way beyond what is reasonable compared to the bedrock principles behind freedom of the press and thus being capable of having a chilling effect on the applicant's freedom of expression. In these cases, it is the financial losses as such, which the Court takes into account when reviewing the proportionality of an impugned measure irrespective of whether they result from fines or other court-related costs and expenses.

This was for instance the case in Ghiulfer Predescu v. Romania, where the applicant, a journalist convicted of defamation, was ordered to publish at her own expense the final domestic judgment in two newspapers, to send a public apology letter to the injured party and to pay the last-mentioned compensation and legal costs. These sanctions were capable of having a chilling effect on the applicant's freedom of expression. ${ }^{51}$

The same held true in Tønsbergs Blad AS and Haukom v. Norway - also a defamation case. The topic of the articles in question was of public interest (concerning property owners suspected of failing to respect the permanent residence requirement applying to certain properties). The Court did not find the reasons relied on by the respondent State sufficient to show that the interference complained of was 'necessary in a democratic society. Hence, regarding the chilling effect, the Court stated:

Nonetheless, the applicants had to defend their cause in judicial defamation proceedings
pursued at three judicial levels. The outcome was that the statements were declared null
and void and the applicants were ordered to pay the plaintiff NOK 50,000 in compen-
sation for non-pecuniary damage and to reimburse him NOK 673,829 for his legal
expenses ... in addition to bearing their own costs. In the circumstances, the proceedings

$50 \quad$ See case Cumpana and Mazare v. Romania para. 118-119.

51 See Ghiulfer Predescu v. Romania, appl. no. 29751/09, para. 61. See also Independent Newspapers (Ireland) Limited v. Ireland, appl. no. 29199/15, 15.06.2017, para. 104. 
resulted in an excessive and disproportionate burden being placed on the applicants, which was capable of having a chilling effect on press freedom in the respondent State. ${ }^{52}$

In Timpul Info-Magazin and Anghel v. Moldova-case, the sanctions imposed on the applicants were so severe that they had forced the newspaper to close down. The article in question criticised a Government practice of purchasing luxury cars, and the lack of transparency regarding the purchase of the cars as no official invitation for bids had been published before the cars had been bought. The article further suggested that certain cars had been overpriced. The topic of the article was, in other words, a matter of genuine public concern. The applicant was nevertheless convicted of defamation. Regarding the chilling effect the Court stated:

While the seriousness of the fine is irrelevant to the outcome of the present case, the Court takes note of its chilling effect on the applicant newspaper, and that its imposition was capable 'of discouraging open discussion of matters of public concern' ... by silencing a dissenting voice altogether. ${ }^{53}$

As establish above, freedom of expression constitutes one of the essential foundations of a democratic society and one of the basic conditions for its progress. The possibility in Article 10 (2) to interfere with freedom of expression must thus not be misused to demolish political opponents or to keep important information hidden from the public.

The Kasabova v. Bulgaria-case and Bozhkov v. Bulgaria-case are interlinked as both of them relate to newspaper articles published in the Bulgarian press, concerning irregularities in the admission procedure to specialised secondary schools. Both judgments were delivered by the same Chamber of the Court, and on the same day the applicants were found guilty of defamation and were made to pay huge sums in compensation for their statements in the articles. The court characterised the articles as

... reporting facts relating to alleged irregularities and corrupt practices in the admission of students to secondary schools. There can be no doubt that this was a question of considerable public interest, even sparking parliamentary debates and a hearing before a parliamentary committee, and that the publication of information about it formed an integral part of the task of the media in a democratic society. ${ }^{54}$

In both cases, the overall sum which the applicants were required to pay in fines and damages, amounted to respectively 57 and 70 minimum monthly salaries at the relevant time. The Court found that this was the most important factor in terms of the potential

52 See Tønsbergs Blad AS and Haukom v. Norway, appl. no. 510/04, 01.03.2007, para. 102.

53 See Timpul Infor-Magasin and Anghel v. Moldova, appl. no. 42864/05, 27.11.2007, para. 39.

$54 \quad$ See Kasabova v. Bulgaria, appl. no. 22385/03, 19.04.2011, para. 56. 
chilling effect of the proceedings on the applicants 'and other journalists.'55 The chilling effect was thus seen as to reach beyond the cases at hand.

\subsubsection{Remarkable cases}

The case Axel Springer SE and RLT Television GmbH v. Germany, concerned the complaint by the two media companies about a judicial order banning the publication of images by which the defendant in a criminal trial for murder could be identified. The defendant was suffering from a schizoid personality disorder. He had confessed to the police to have killed his parents. Taking images as such - also in the national courts premises - had not been limited, the order had only banned the publication of images in which the defendant could be identified. It was not included in the ban to publish photos of the defendant as long as they were made unidentifiable, for instance by blurring them. The only consequence of a breach of the court order was a potential barring from further reporting on the case.

The Court found such consequence limited. As regards the ban itself, the Court noted that it was not a particularly severe restriction on reporting, since it was the least restrictive of several possible measures in order to safeguard due process and protect the defendant's privacy. In addition to this, any other reporting on the proceedings was not restricted. The Court did not find a violation of Article 10, and added that the order had not had any chilling effect on the applicants' rights under Article $10 .{ }^{56}$ In other words, the press was still able - in spite of the ban - to perform the role of a public watchdog and report from the case.

Axel Springer AG v. Germany (no. 2) regarded an order prohibiting the newspaper Bild from republishing a part of a formerly published article concerning Mr Schröder (former Chancellor of Germany), his reasons to resign from his political functions and his motives to decide to call for an early election. It was indicated in the article by another politician from the German Parliament that Mr Schröder's reassignment solely was caused by the fact that he had been offered a lucrative post in a German-Russian consortium (Konsortium Nordeuropäische Gaspipeline). The article thus raised the question whether, and to what extent, the former Chancellor had taken advantage of policy decisions he himself had made while head of government in preparation for this change. ${ }^{57}$ The Court stated that the subject of the article clearly was of considerable public interest and related only to Mr Schröder's conduct in the exercise of his term of office as Federal

55 See case Kasabova v. Bulgaria para. 71 and Bozhkov v. Bulgaria, appl. no. 3316/04, 19.04.2011, para. 55.

56 See case Axel Springer SE and RTL Televions GmbH v. Germany para. 57.

$57 \quad$ See Axel Springer AG v. Germany (No. 2), appl. no. 48311/10, 10.07.2014, para. 58. 
Chancellor and his controversial appointment to the consortium shortly after he ceased to hold office as Chancellor - not his private life. The Court found a violation of Article 10. As regards any chilling effect, the Court stated:

Lastly, as regards the severity of the sanction imposed, the Court notes that the only measure taken against the applicant company was a civil-law injunction prohibiting further publication of a passage from the article... It nevertheless considers that the injunction could have had a chilling effect on the exercise of the applicant company's freedom of expression. ${ }^{58}$

With reference to the Court's common approach to prior restraint, this statement seems moderate.$^{59}$ It is, however, important to appreciate in this connection that the prohibition to republish only concerned the opinions of the other politician - not to report on the subject as such.

The Court was more direct and straightforward in Cumhuriyet Vakfi and Others v. Turkey. The case concerned an injunction issued in 2007 against the applicants, preventing further publication of a political advertisement allegedly quoting an interview given by (at the injunction time) the current Turkish President to The Guardian newspaper in 1995. The Court found a violation of Article 10 mainly because it was not made clear in the injunction what exactly Cumhuriyet (the applicant newspaper) had been banned from publishing. Regarding the chilling effect the Court stated:

\begin{abstract}
The Court considers it quite possible that this lack of certainty may have also had a general chilling effect on the reporting of these matters at a period of intense political debate regarding the presidential election, thereby affecting not only Cumhuriyet as the measure's direct addressee but all media outlets in the country. The Applicants in fact claim that neither Cumhuriyet nor the other major newspapers in Turkey had even reported on the interim injunction order obtained by $\mathrm{Mr} \mathrm{Gül.} .^{60}$
\end{abstract}

The Wizerkaniuk v. Poland case concerns the journalistic practise, concretely the question if it is a violation of journalistic freedom of expression if a journalist is punished for publishing an interview without the authorisation of the person interviewed. The Court found a violation of Article 10. Regarding the chilling effect, the Court stated:

$58 \quad$ See case Axel Springer AG v. Germany (No. 2) para. 76.

59 The Court's approach was even more moderate in Verlagsgruppe Handelsblatt GmbH \& Co. KG v. Germany, appl. no. 52205/11, 15.03 .2016 (dec.), para. 28, where the Court did not find a violation of Article 10 although the domestic courts had ordered the applicant to refrain from any further publication of a manipulated photomontage. The Court stated that this sanction was lenient and therefore had not any chilling effect. See Cumhuriyet Vakfi and Others v. Turkey, appl. no. 28255/07, 08.10.2013, para. 63. 


\begin{abstract}
Moreover, the legal provisions concerned in the present case could have other negative consequences prior to publication, in that they were capable of making journalists avoid putting probing questions for fear that their interlocutors might later block the publication of the entire interview by refusing to grant authorisation, or choose interlocutors known for being co-operative, to the detriment of the quality of the public debate. The Court shares the view expressed by ... [one of the Constitutional Court judges] in his dissenting opinion ... that these provisions were therefore capable of having a chilling effect on the exercise of the journalistic profession by going to the heart of decisions on the substance of press interviews and shares. ${ }^{61}$
\end{abstract}

In Mosley v. the United Kingdom, the applicant was the person exposed. He claimed that it was a violation of his right to privacy in accordance with Article 8 of the Convention that the media did not have a legal duty to notify a person in advance of their intention to publish material concerning that person, thus giving the person the opportunity to ask a court for an interim injunction in order to prevent the material's publication. The Court did not find in favour of the applicant. Regarding any chilling effect the Court on various theoretical questions stated:

The Court considers that in order to prevent a serious chilling effect on freedom of expression, a reasonable belief that there was a 'public interest' at stake would have to be sufficient to justify non-notification, even if it were subsequently held that no such 'public interest' arose. The parties' submissions appeared to differ on whether 'public interest' should be limited to a specific public interest in not notifying (for example, where there was a risk of destruction of evidence) or extend to more general public interest in publication of the material. The Court would observe that a narrowly defined public interest exception would increase the chilling effect of any pre-notification duty.

Second, and more importantly, any pre-notification requirement would only be as strong as the sanctions imposed for failing to observe it. A regulatory or civil fine, unless set at a punitively high level, would be unlikely to deter newspapers from publishing private material without pre-notification...

Although punitive fines or criminal sanctions could be effective in encouraging compliance with any pre-notification requirement, the Court considers that these would run the risk of being incompatible with the requirements of Article 10 of the Convention. It reiterates in this regard the need to take particular care when examining restraints, which might operate as a form of censorship prior to publication. It is satisfied that the threat of criminal sanctions or punitive fines would create a chilling effect, which would 
be felt in the spheres of political reporting and investigative journalism, both of which attract a high level of protection under the Convention...

\begin{abstract}
However, the Court has consistently emphasised the need to look beyond the facts of the present case and to consider the broader impact of a pre-notification requirement. The limited scope under Article 10 for restrictions on the freedom of the press to publish material which contributes to debate on matters of general public interest must be borne in mind. Thus, having regard to the chilling effect to which a pre-notification requirement risks giving rise, to the significant doubts as to the effectiveness of any pre-notification requirement and to the wide margin of appreciation in this area, the Court is of the view that Article 8 does not require a legally binding pre-notification requirement.... ${ }^{62}$
\end{abstract}

The last case to be mentioned in this category is the case Tavares de Almeida Fernandes and Almeida Fernandes v. Portugal. This case is not just remarkable but also exceptional. The relevant facts can be summed up to this: The first applicant, a journalist and editor, was convicted of defamation and was ordered to pay EUR 60.000 in non-pecuniary damage in compensation. ${ }^{63}$ The second applicant had not had any involvement in the defaming article, but she was ordered by the domestic courts to jointly pay the compensation sum. The only thing to 'reproach' her was the fact that she was married to the first applicant and that, as she had no independent income, 'her husband's income directly benefited both of them.' ${ }^{64}$ The Court stated that this 'collective responsibility' has a serious chilling effect on the freedom of the press. ${ }^{65}$

In all the 'remarkable cases' the chilling effect had a broader impact on the press' opportunities to perform its vital role as the public watchdog in the future.

\title{
4. Concluding Remarks and Perspectives
}

The term 'chilling effect' has by the Court not been made in to a 'Convention notion' in the sense that the Court has defined it in any substantial way. However, the term must be considered as a legal concept, which indicates that something striking is at stake. That is also evident from the word itself - 'chilling. That something striking is at stake is also due to the fact that the Court reserves the term to special circumstances and does not use it randomly.

62 See Mosley v. the United Kingdom, appl. no. 48009/08, 10.05.2011, para. $127 \mathrm{ff}$.

63 Plus interest.

64 See Tavares de Almeida Fernandes and Almeida Fernandes v. Portugal, appl. no. 31566/13, 17.01.2017, para. 16 . 
The term 'chilling effect' is not, however, used by the Court in a totally consistent way. Though, some tendencies may be deduced from the cases examined above.

First, the 'chilling effect'-term is used in connection with restrictions or sanctions that can have a negative influence on the objective and purpose of freedom of the press. This was seen regarding the deprivation of a journalist to exercise her or his profession or where the sanction imposed was capable of discouraging open discussion of matters of public concern because of its financial consequences and, with similar effect, where a journalist was faced with (the threat) of imprisonment. The same goes where the journalist was ordered to disclose a source. In such instances, the Court emphasises that the chilling effect proceeds the individual measure and thereby has the potential to have a more extensive adverse impact for an open and unhindered public debate on matters of public concern. If journalists are not allowed to work, or are hindered in their work because of captivity or of fear of captivity, or the media are closed down due to the extent of the sanction, or if sources do not dare to come forward by fear of disclosing, the public is debarred from receiving important information. The chilling effect thereof does not afflict only the subject journalist or media but also society as a whole because of the silencing of the press. Therefore, such measures amount to a risk for democracy. The chilling effect of the measures obviously go beyond the cases in hand.

Regardless of an imposed sanction, the Court has in some cases a special firm eye to the chilling effect of a criminal conviction itself. This is particularly so where the domestic authorities abuse their power to silence journalists in sensitive but very important issues. The legitimate aims of protection of national security against terrorism or crime and disorder, is a fact that the Court is particularly aware of. The chilling effect of these cases, however, goes way beyond the cases in hand.

If a conviction was legitimate, and had no adverse material consequences for the journalist's work-to-be, and the sanction imposed did not in itself have a chilling effect, the conviction could hardly have any chilling effect even though the journalist was convicted in the line of duty. On the other hand, if the conviction - even though the sanction imposed was relatively modest - has a symbolic value, the conviction could still have a chilling effect on the applicant and other participants in the public debate. This goes if the topic of the articles in question is of public interest. The domestic authorities cannot escape the Court's eyes by imposing lenient sanctions if the conviction in itself, because of the symbolic value, have a chilling effect. The symbolic value goes, namely, beyond the matter before the Court.

Any kind of prior restraint on the media consisting of prohibitions to report on a specific topic or a named person in what form it takes, is always dangerous for the journalist or media in question. Such measures are, however, also dangerous to the rest of the media in the state concerned. Thus, the chilling effect of such measures reaches far beyond the cases in hand and are detriment not just to the quality of the public debate, but also to the 
exercise of the journalistic profession and thereby to society as such. Prior restraints have an inherent chilling effect to the public debate and the public's right to receive information on all matters of public interest.

As regard the last mentioned case, Tavares de Almeida Fernandes and Almeida Fernandes v. Portugal, it is understood that it has a chilling effect on freedom of expression and society as such if an individual - without making a statement him- or herself - can go to trial and be taken down solely because of statements made by another. Such convictions contravene the democratic society governed by the rule of law. In Denmark (and presumably in Norway), we have a phrase saying that it is a perverting of justice and against the rule of law if the authorities convict the (innocent) 'baker' instead of the (guilty) 'smith.'6 The same is true if both the baker and the smith are convicted for the smith's single-handed offence.

Even though it is not possible by means of the Court's case law to establish a precise definition of the term 'chilling effect', the concept is not just a substitute for a non-proportional restriction or sanction. It is not a substitute for (criminal) deterrence, either. The notion has an unassisted content. Firstly, this is true because the term is only used in relatively few of all the judgments where the Court finds a violation of Article 10 of the Convention. Secondly, it is true since chilling effect does not only point at unlawful expressions, but also - and foremost - at expressions not illegal in themselves. Thirdly, it is true because the notion points beyond the case in question and to the applicant's work to-be. The chilling effect has thus a negative impact on the applicant's future task in informing the public on matters of public concern or in orchestrating the public debate. The chilling effect may also discourage the journalist from publishing (further) critical materials on matters of public interest.

The most severe form of chilling effect is, however, if it has a negative impact on the press as such - to the outmost detriment of the public debate, the control of the establishment, and, thereby, to the impairment of society as a whole.

One could ask if the notion of chilling effect were not better placed in the non-proportional-category - maybe, as suggested in the beginning of this article, as the outermost limit of proportionality? The question is relevant, since non-proportionality in the final analysis simply means that there is not a fair correlation (ratio) between the offence and the result of the case. This categorisation tends, however, to overlook the negative impact on the press in the time to come. In other words, placing chilling effect in the non-proportional-category will drown the idea and purpose of the term as a communication cord in exceptional cases.

66 The phrase is from a poem written by the Danish/Norwegian poet Johan Herman Wessel called The Smith and the Baker (1784) regarding the power of the law and the administration of justice and the court's lack of ratio. 
'Chilling effect' is a strong notion. It is not to be used only to the benefit of the press, but must be reserved to cases where something genuine is at stake. In return, it must be taken very serious whenever a measure taken or a sanction imposed amount to have a chilling effect - to the benefit of the public, the society and the freedom of the press. 